Available online at http://bajas.edu.iq

https://doi.org/10.37077/25200860.2019.200 College of Agriculture, University of Basrah

ISSN $1814-5868$

Basrah J. Agric. Sci., 32(2): 95-105, 2019

Basrah Journal of Agricultural Sciences

\title{
Effect of Micronutrients Application and Spraying Yeast Extract on Yield and Yield Components of Wheat (Triticum aestivum L.)
}

\author{
Miraje M.M. Al-Shamary* \& Kadhim H. Huthily \\ Department of Field Crop, College of Agriculture, University of Basrah, Iraq \\ *Corresponding author E-mail: dlo75113@gmail.com \\ Received 22 October 2018; Accepted 22 November 2019; 31 December 2019
}

\begin{abstract}
A field experiment was conducted during winter season of 2018-2019, at Al-Qurna district (75 km north of Basrah city centre). The aim of experiment was studding the effect of five levels of micronutrients ( $\mathrm{MN}$ ), Fe, $\mathrm{Zn}, \mathrm{Mn}, \mathrm{Cu}, \mathrm{B}$, and Mo: 0, 2 and $4 \mathrm{~kg}$. ha ${ }^{-1}$ (soil application), 500 and $1000 \mathrm{ppm}$ (foliar application), and three levels of activated yeast extract (AYE): 0,3 and $6 \mathrm{~g}$. $\mathrm{L}^{-1}$, in the yield and qualitative characteristics of wheat. The experiment was carried out using randomized completely block design in a split arrangement with three replicates. The main plots contained fertilizer levels. While the sub-plot occupied by Yeast levels. The results showed that spraying $1000 \mathrm{ppm}$ from the solution of MN significantly increase the number of spikes per $\mathrm{m}^{2}$, the number of grains in the spike, grain yield and biological yield with an increase by $15.4 \%, 18 \%, 27.5 \%$ and $35 \%$ respectively compared to the control treatment, while the concentration of $500 \mathrm{ppm}$ significantly increase protein yield with an increase of $35 \%$ compared to the control treatment. The results also showed that spraying $6 \mathrm{~g}$. $\mathrm{L}^{-1}$ of AYE differ significantly and gave the highest values of spikes number per $\mathrm{m}^{2}$, number of grains per spike, grain yield, biological yield and protein yield, with an increase by $5.84 \%, 7.1 \%, 11.4 \%, 11.1 \%$ and $10.9 \%$ respectively compared to the control treatment. The interaction between application of $4 \mathrm{~kg}$. MN ha-1 and the level of $6 \mathrm{~g}$. $\mathrm{L}^{-1}$ AYE gave a significant superiority in the number of spikes (333.9 spike $\mathrm{m}^{-2}$ ), while the spraying of $1000 \mathrm{ppm}+6 \mathrm{~g} \cdot \mathrm{L}^{-1}$ AYE gave the highest grain yield (8.891 ton. ha-1) and biological yield (31.827 ton. ha-1).
\end{abstract}

Keywords: Triticum aestivum L., Yield components, Seed yield, Protein yield.

\section{Introduction:}

Wheat (Triticum aestivum L.) is one of the most important strategic crops for its high nutritional value. Iraq is one of the first places for the emergence of wheat crop because of the availability of production factors such as soil, water and suitable climatic conditions, but the productivity of the crop fluctuates from year to year. In general, there is a gap between the amount of production and the actual need of the population. Most soils of the central and southern regions of Iraq tend to be alkaline with a $\mathrm{pH}$ ranging from 7.5-8.2 depending on their lime content (Khalaf et al., 2017). This makes micronutrients such as iron, manganese, zinc, 


\section{Al-Shamary \& Huthily. / Basrah J. Agric. Sci., 32(2):105-115, 2019}

and copper precipitate in the form of complex compounds and become unavailable for the plant (Abu-Dahi, 1995). Numerous researches have shown that the best method to add $\mathrm{MN}$ to the plant to obtain a good quantitative and qualitative production is by spraying it on the vegetative part. Abu-Dahi \& Shati (2009) found that the use of chelated fertilizer containing a combination of micronutrients led to an increase in dry weight, weight of thousand grain and grain yield of wheat. Al-Zergawy (2016) obtained an increase in the number of spikes and weight of 1000 grains and the grain yield of wheat when spraying with micronutrients (N 40\%, P 10\%, K 0.10\%, Mg $0.25 \%$, Ca $0.10 \%$, S 1\%, Fe 700 ppm, Zn 700 ppm, Cu 600 ppm, Mo 80 ppm and B 30 ppm) at a concentration of $0.01 \mathrm{~g}$. $\mathrm{L}^{-1}$. Al-Tameme (2013) found significant increase in number of spike $\mathrm{m}^{-2}$, weight of 1000 grains, grain yield and biological yield of two cultivars of wheat (Iba 99 and Buhooth 7) when sprayed in combination (50 mg Fe and $50 \mathrm{mg} \mathrm{Zn.} \mathrm{l}^{-1}$ ).

Some research has been done on the use of AYE as biofertilizer for some crops. Yeast (Saccharomyces cerevisiae) is a living organism (fungi) that contains many important nutrients for plants such as iron, calcium, magnesium, potassium, nitrogen, sodium, phosphorus, zinc and silicon (Table 2). It is rich in growth regulators such as gibberellins and oxins (De Wedar \& Ibrahim, 2016). It was found that AYE increase vegetative growth such as plant height and leaf area (Ezz El-Din \& Hendawy, 2010). El-Desouky et al. (2007) noted that yeast extract has a role in encouraging cells to grow, divide, elongate and increase plant height and leaf area because of the nutrients they contain. Al-Maeini \& Al-
Isawi (2017) observed that the concentration exceeded $15 \mathrm{~g}$. $\mathrm{L}^{-1}$ of AYE significantly increased the number of grains in the head and grain yield for sorghum which reached 11.72 ton. $\mathrm{ha}^{-1}$. It was also observed that spraying with AYE on maize plants at levels 10, 20 and 30 g. $\mathrm{L}^{-1}$ showed significant differences and increases for most growth and yield characteristics compared to no spraying in both spring and autumn seasons (Al-Ani \& AlObeidi, 2017).

Due to unavailability of micronutrients in the soil of southern of Iraq, and the lack of studies on the addition methods, as well as the scarcity of studies on spraying plants with AYE, this study was carried out, aimed to knowing the response of wheat to applying micronutrient (in different quantities concentration and different methods) and the effectiveness of spraying plants with AYE.

\section{Materials \& Methods}

A field experiment was carried out during the winter season of 2018-2019, in order to study the impact of five levels of micronutrients $(\mathrm{MN}), \mathrm{Fe}, \mathrm{Zn}, \mathrm{Mn}, \mathrm{Cu}, \mathrm{B}$, and Mo: 0, 2, $4 \mathrm{~kg}$. $\mathrm{ha}^{-1}$ (soil application) and 500 and $1000 \mathrm{ppm}$ (foliar application), and three levels of activated yeast extract (AYE): 0, 3 and $6 \mathrm{~g}$. $\mathrm{L}^{-1}$; in the yield and qualitative characteristics of wheat. The experiment was carried out using randomized completely block design in a split arrangement with three replicates. The main plots occupied by fertilizer levels. The subplots occupied by yeast levels. The field of experiment was prepared by (plowing and leveling). Thereafter, five random soil samples were taken from the soil to determine some physical and chemical properties, shown in 
table (1) (Salim \& Ali, 2017). Field was divided into three blocks (replicates), each block into five main plots, and each main plot to three sub-plots (experimental units) with dimensions of $(2 \times 3) \mathrm{m}^{2}$, A distance of $1.5 \mathrm{~m}$ has been left between each blocks. Each experimental unit included 13 rows which were opened manually, the distance between the rows was $15 \mathrm{~cm}$ with $3 \mathrm{~m}$ length. The seeds of wheat $\mathrm{cv}$. Buhooth 22 were sown at 1/12/2018 with a seeds rate of $120 \mathrm{~kg} \mathrm{ha}^{-1}$. The five levels of MN symbolized by $F_{0}, F_{1}, F_{2}, F_{3}$ and $F_{4}$, respectively.

Table (1): Some physical and chemical properties of the soil before sowing.

\begin{tabular}{ccccc}
\hline & $\mathrm{P}\left(\mathrm{mg} \mathrm{kg}^{-1}\right)$ & $\mathrm{K}\left(\mathrm{mg} \mathrm{kg}^{-1}\right)$ & $\mathrm{pH}$ & $\mathrm{E} . \mathrm{Ce}\left(\mathrm{dSm}^{-1}\right)$ \\
\hline 69 & 17 & 182 & 7.56 & 4.12 \\
\hline & & \multicolumn{3}{c}{ Soil particles $\left({\left.\mathrm{gm} . ~ \mathrm{~kg}^{-1}\right)}\right.$} \\
\hline $\begin{array}{c}\text { Clay } \\
\text { loam }\end{array}$ & Soil texture & Clay & Silt & Sand \\
\cline { 3 - 5 } & & 401.6 & 391.7 & 272.7 \\
\hline
\end{tabular}

Table (2): Some components of activated yeast ( $\mathrm{mg}$ per $100 \mathrm{~g}$ dry yeast) cited from Neama et al. (2014).

\begin{tabular}{|c|c|c|c|c|c|}
\hline Arginine & 1.99 & Serine & 1.59 & Inositol & 0.26 \\
\hline Histidine & 2.63 & Aspartic acid & 1.33 & Biotin & 0.09 \\
\hline Isoleucine & 2.31 & Cysteine & 0.23 & Nicotinic acid & 39.90 \\
\hline Lucien & 3.09 & Proline & 1.53 & Pantothenic acid & 19.60 \\
\hline Lysine & 2.95 & Tyrosine & 1.49 & Folic acid & 4.36 \\
\hline Methionine & 0.72 & Vit. $B_{1}$ & 2.23 & Pyridoxine & 2.90 \\
\hline Phenylalanine & 2.01 & Vit. $B_{2}$ & 1.33 & \multirow{2}{*}{$\begin{array}{l}\text { Total } \\
\text { carbohydrates }\end{array}$} & \multirow{2}{*}{23.20} \\
\hline Threonine & 2.09 & Vit. $B_{6}$ & 1.25 & & \\
\hline Tryptophan & 0.45 & Vit. $B_{12}$ & 0.15 & Glucose & 13.30 \\
\hline Valine & 2.19 & Glutamic acid & 2.00 & Cobalamine & 153.0 \\
\hline $\mathrm{Fe}$ & 50.00 & $\mathrm{Cu}$ & 50.00 & $\mathrm{Zn}$ & 50.00 \\
\hline $\mathrm{Ca}$ & 100 & $\mathrm{Mg}$ & 2000 & Co & 5.00 \\
\hline $\mathrm{Na}$ & 5600 & $\mathrm{P}$ & 38000 & K & 30000 \\
\hline
\end{tabular}


Soil application of $\mathrm{MN}\left(\mathrm{F}_{1} \& \mathrm{~F}_{2}\right)$ was applied at sowing time, while the $\mathrm{MN}$ solution was sprayed at deferent timing one, two, and three months after sowing. The three levels of AYE solution had the symbols: $\mathrm{Y}_{0}, \mathrm{Y}_{1}$, and $\mathrm{Y}_{2}$ respectively. The solution of AYE was prepared in the laboratory of College of Agriculture, University of Basrah, according to the method described by Spencer et al. (1983). Some components of activated yeast illustrated in table (2). The AYE was sprayed after 35, 70, and 105 days after sowing. The compound fertilizer NPK (20-20-20) was evenly added to all experimental units by $200 \mathrm{~kg}$. ha ${ }^{-1}$ in one batch before sowing (when preparing the field).
Before flowering, $60 \mathrm{~kg} \mathrm{~N}$. ha ${ }^{-1}$ as urea $(46 \%$ $\mathrm{N})$ were applied. The plants were harvested after reaching full maturity at 16/4/2019. Data were collected and analyzed using SPSS program ver. 17 for analysis of variance and the least significant difference at 0.05 level was used to compare the means of treatments. Random samples were taken from the field to determine their physical and chemical properties, (table 1). Number of spikes. $\mathrm{m}^{-2}$, number of grain per spike, weight of 1000 grains, grain yield, biological yield and protein yield were studied. The composition of $\mathrm{MN}$ solution is shown in table (3).

Table (3): Micronutrient concentration(\%) in spraying solution.

\begin{tabular}{ccccccc}
\hline Element & $\mathrm{Fe}$ & $\mathrm{Zn}$ & $\mathrm{Mn}$ & $\mathrm{Cu}$ & $\mathrm{B}$ & $\mathrm{Mo}$ \\
\hline$\%$ & 33.3 & 25.0 & 16.7 & 13.3 & 8.3 & 3.3 \\
\hline
\end{tabular}

\section{Results \& Discussion}

\section{Number of spikes $\mathbf{m}^{-2}$}

The results in table (4) indicated a significant increase in the number of spikes per square meter when using $\mathrm{MN}$ in spraying method. Concentration of $1000 \mathrm{ppm}\left(\mathrm{F}_{4}\right)$ gave the highest number of spikes of $326.8 \mathrm{~m}^{-2}$ (which was not significantly differed from treatment $\mathrm{F}_{3}$ ) with an increase by $15.4 \%$ compared to the control treatment, which gave the lowest average of 283.2 spike $\mathrm{m}^{-2}$. This may be due to the active and positive role of some $\mathrm{MN}$ in transporting carbohydrates from sources to sinks, providing them in the suitable time (critical stage) to modern and efficient growth centers, which gave an opportunity for the growth and development of fertile tillers. These processes reflected on the increase in the number of spikes (Rawashdeh \& Sala, 2014), in addition, iron and manganese takes an important role in building good roots (AbuDahi \& Shati, 2009). This leads to an increase in the number of spikes per unit area, due to the strong and positive correlation between them (Al-Alusi, 2002). From result of table (4) we also noted the significant effect of spraying with AYE in increasing the number of spikes, where the level of $6 \mathrm{~g}$. $\mathrm{L}^{-1}\left(\mathrm{Y}_{2}\right)$ gave the highest number of spikes $\left(319.9 \mathrm{~m}^{-2}\right)$ with an increase by 5.84 and $4.10 \%$ compared to $\mathrm{Y}_{0}$ and $\mathrm{Y}_{1}$ respectively. This may be due to the containing of yeast extract on various nutrients mineral elements that have a role in encouraging plant 
cells to grow, divide, elongate and increase the leaf area, resulting in more efficient photosynthesis and consequently increasing the number of tiller carrying spikes (Al-Hamdani et al., 2014; Mohamed et al., 2018) This result was agreed with Ismail \& Amin, (2014).

The interaction between $\mathrm{MN}$ and spraying with AYE showed a significant effect on the number of spikes $\mathrm{m}^{-2}$. Treatment $\mathrm{F}_{0} \mathrm{Y}_{0}$ gave the lowest number of spikes $\left(271.1 \mathrm{~m}^{-2}\right)$. The heights number obtained by $\mathrm{F}_{2} \mathrm{Y}_{2}, \mathrm{~F}_{2} \mathrm{Y}_{3}$ and $\mathrm{F}_{2} \mathrm{Y}_{4}$. Here, the contribution of both of the two factors to increase indicatory of growth, including the leaf area, may encourage the other factor to increase the area of foliar spray and the greater response of the plant in absorbing a larger amount of MN or AYE.

Table (4): Effect of micronutrients, spraying with AYE and their interaction on number of spikes $\mathbf{m}^{-2}$ for wheat.

\begin{tabular}{ccccccc}
\hline \multirow{8}{*}{ Yeast levels } & \multicolumn{7}{c}{ Micronutrients levels } & \multirow{2}{*}{ Mean for Yeast } \\
\cline { 2 - 6 } & $\mathrm{F}_{0}$ & $\mathrm{~F}_{1}$ & $\mathrm{~F}_{2}$ & $\mathrm{~F}_{3}$ & $\mathrm{~F}_{4}$ & \\
\hline $\mathrm{Y}_{0}$ & 271.1 & 301.6 & 312.2 & 308.3 & 317.6 & 302.2 \\
\hline $\mathrm{Y}_{1}$ & 274.5 & 295.0 & 308.8 & 327.1 & 330.9 & 307.3 \\
\hline $\mathrm{Y}_{2}$ & 304.0 & 298.0 & 333.9 & 331.6 & 331.8 & 319.9 \\
\hline $\begin{array}{c}\text { Mean for } \\
\text { Micronutrient } \\
\mathrm{s}\end{array}$ & 283.2 & 298.3 & 318.3 & 322.3 & 326.8 & \\
\hline $\begin{array}{c}\text { L.S.D. } \\
(\mathrm{P}<0.05)\end{array}$ & Micronutrients & \multicolumn{2}{c}{ Yeast } & \multicolumn{2}{c}{ Interaction } \\
\cline { 2 - 5 } & \multicolumn{2}{c}{19.01} & 6.17 & \multicolumn{2}{c}{13.79} \\
\hline
\end{tabular}

\section{The number of grain per spike}

Results in table (5) indicated a significant increase in grains number in the spike by applying $\mathrm{F}_{4}$, which gave the highest number of grains in spike (80.3), with a significant increase by $18 \%$ over the control treatment $\left(\mathrm{F}_{0}\right)$, which gave the lowest value (68.0 grain per spike). This is due to the role of $\mathrm{MN}$, including the importance of boron in increasing pollen germination and reducing the fatigue of ovule, the fact that the fertility rate in flowers is affected by nutrition in addition to being affected by genetic makeup (Al-Hassan, 2017), and this result agreed with (Al-Jumailly, 2011). The results of table (5) also indicate the significant effect of spraying AYE on the number of grains in the spike. This is due to the active role of yeast in vegetative growth by 
Al-Shamary \& Huthily. / Basrah J. Agric. Sci., 32(2):105-115, 2019

Table (5): Effect of micronutrients, spraying with AYE and their interaction on the number of grains in spike for wheat.

\begin{tabular}{ccccccc}
\hline \multirow{2}{*}{ Yeast levels } & \multicolumn{5}{c}{ Micronutrients levels } & $\begin{array}{c}\text { Mean for } \\
\text { Yeast }\end{array}$ \\
\cline { 2 - 7 } & $\mathrm{F}_{0}$ & $\mathrm{~F}_{1}$ & $\mathrm{~F}_{2}$ & $\mathrm{~F}_{3}$ & $\mathrm{~F}_{4}$ & 70.5 \\
\hline $\mathrm{Y}_{0}$ & 68.3 & 65.0 & 65.0 & 75.0 & 79.0 & 73.0 \\
\hline $\mathrm{Y}_{1}$ & 63.7 & 74.0 & 70.3 & 75.0 & 82.0 & 75.5 \\
\hline $\mathrm{Y}_{2}$ & 72.0 & 73.7 & 79.0 & 73.0 & 80.0 & \\
\hline $\begin{array}{c}\text { Mean for } \\
\text { Micronutrients }\end{array}$ & 68.0 & 70.9 & 71.4 & 74.3 & 80.3 & Interaction \\
\hline L.S.D. (P<0.05) & Micronutrients & \multicolumn{2}{c}{ Yeast } \\
\cline { 2 - 7 }
\end{tabular}

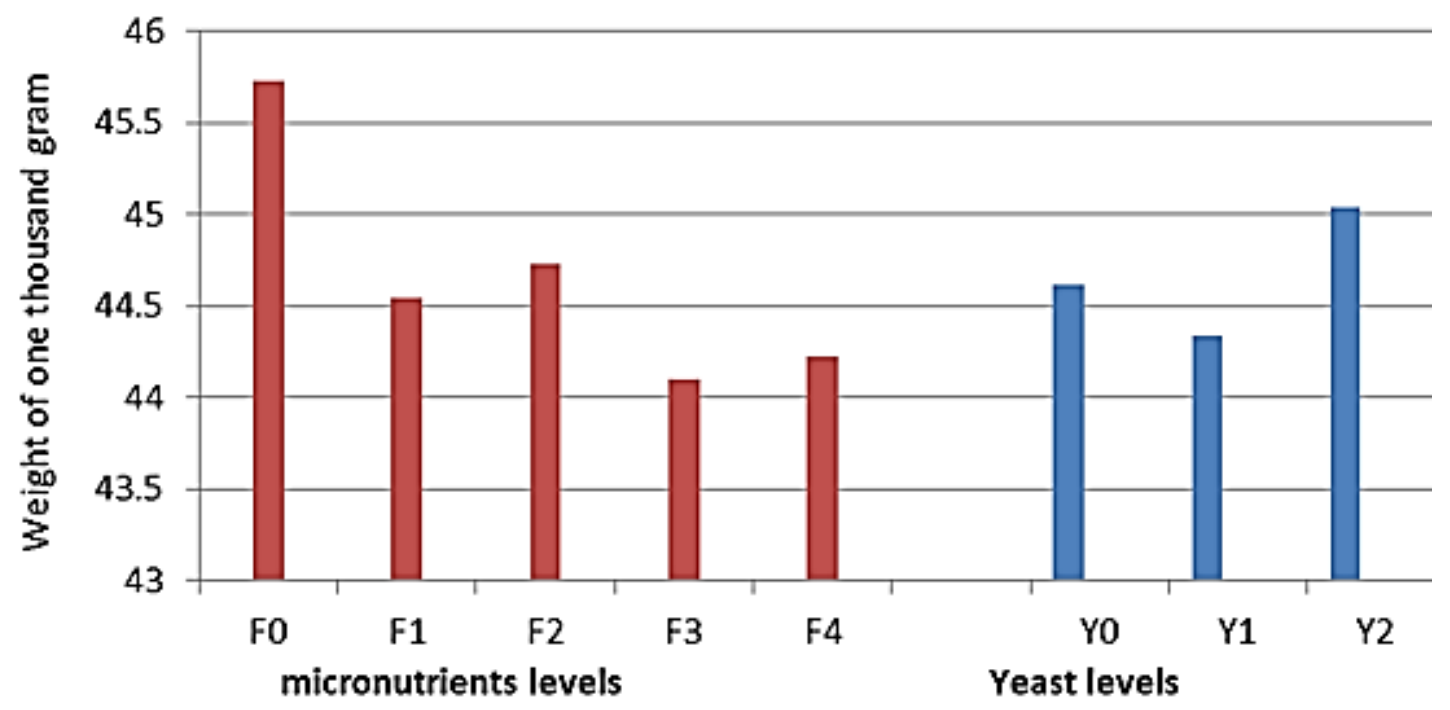

Fig. (1): Effect of micronutrients and spraying with AYE on weight of 1000 grains (gm) of wheat.

absorbing it from the leaves and the fact that the leaves are an and the lowest value was obtained (no significant difference) at $\mathrm{F}_{3}$ and $\mathrm{F}_{4}$ (44.1 and $44.2 \mathrm{~g})$ respectively. The yield components cannot take the same trend of increase or decrease at the same time. As the increase in the number of spikes $\mathrm{m}^{-2}$ (table 4) and the increase in the number of grains in the spike (table 5) were offset by the unaffected weight of the grain or there may be a decrease in weight (fig. 1). 


\section{Grain yield}

The results in table (6) showed that the grain yield had been found to been increased progressively irrespective of $\mathrm{MN}$ application. The highest amount of grain yield of wheat being reached 8.596 ton. $\mathrm{ha}^{-1}$ by foliar application $\left(\mathrm{F}_{4}\right)$, with an increasing percentage by $27.5 \%$ compared to $\mathrm{F}_{0}$ which gave the lowest value $\left(6.740\right.$ ton. ha $\left.{ }^{-1}\right)$. This increase might be due to the increase in the number of spikes per $\mathrm{m}^{2}$ and the number of grains in the spike, which positively lead to the increase grain yield (tables $4 \& 5$ ).

Table (6): Effect of micronutrients, spraying with AYE and their interaction on grain yield of wheat (ton. ha-1).

\begin{tabular}{|c|c|c|c|c|c|c|}
\hline \multirow{2}{*}{ Yeast levels } & \multicolumn{5}{|c|}{ Micronutrients levels } & \multirow{2}{*}{ Mean for Yeast } \\
\hline & $\mathrm{F}_{0}$ & $\mathrm{~F}_{1}$ & $\mathrm{~F}_{2}$ & $\mathrm{~F}_{3}$ & $\mathrm{~F}_{4}$ & \\
\hline $\mathrm{Y}_{0}$ & 6.663 & 6.678 & 6.958 & 7.841 & 8.349 & 7.298 \\
\hline $\mathrm{Y}_{1}$ & 6.156 & 7.284 & 7.493 & 7.887 & 8.549 & 7.474 \\
\hline $\mathrm{Y}_{2}$ & 7.401 & 7.484 & 8.729 & 8.186 & 8.891 & 8.138 \\
\hline $\begin{array}{c}\text { Mean for } \\
\text { Micronutrients }\end{array}$ & 6.740 & 7.149 & 7.726 & 7.971 & 8.596 & \\
\hline \multirow{2}{*}{ L.S.D. $(\mathrm{P}<0.05)$} & \multicolumn{2}{|c|}{ Micronutrients } & \multicolumn{2}{|c|}{ Yeast } & \multicolumn{2}{|c|}{ Interaction } \\
\hline & \multicolumn{2}{|c|}{0.644} & \multicolumn{2}{|c|}{0.267} & \multicolumn{2}{|r|}{0.599} \\
\hline
\end{tabular}

The results in table (6) also showed the positive and significant effect of AYE in an increasing wheat grain yield. The highest yield observed was 8.138 ton. ha ${ }^{-1}$ recorded by using $\mathrm{Y}_{2}$ treatment with an increase of $11.4 \%$ as compared to the non-sprayed yeast treatment $\left(\mathrm{Y}_{0}\right)$ which gave the lowest yield (7.294 ton. ha$\left.{ }^{1}\right)$. This may be due to the nutrient and another content of AYE, which reflected positively in an increasing the vegetative growth through the development of the plant and leaf area (Sarhan et al., 2011). These lead to increase photosynthesis and biological processing reflected on increasing the number of spikes and the number of grains in the spike and then increase the total grain yield (Al-Ani \& AlObeidi, 2017). The finding of Sarhan et al. (2011) supported these results. The effect of the interaction between the two factors was significant in this parameter. The highest value obtained by using $\mathrm{F}_{4} \mathrm{Y}_{2}$ and $\mathrm{F}_{2} \mathrm{Y}_{2}$ (8.891 and 8.729 ton. ha $^{-2}$ respectively), while the lowest value obtained by using $\mathrm{F}_{0} \mathrm{Y}_{1}$ (6.156 ton. ha ${ }^{-2}$ ). Such increase in grain yield might be due to the high effect of spraying $\mathrm{MN}$ which increase leaf area and then resulted in receive more amount of AYE causing relatively greater effect on 
yield components reflected on giving the highest yield of wheat grain.

\section{Biological yield (BY)}

Results of table (7) indicated the positive significant effect of spraying with $\mathrm{MN}$ on biological yield. The highest biological yield (BY) (30.670 ton. ha ${ }^{-1}$ ) was obtained when the plants sprayed by $1000 \mathrm{ppm}$ (F4) of $\mathrm{MN}$ solution, while the lowest (22.711 ton. ha ${ }^{-1}$ ) was obtained when the plants sprayed by $\mathrm{F}_{0}$. This is due to the role of $\mathrm{MN}$ in an increasing the weight of the vegetative parts and grain yield and thus lead to increase the biological yield (Khalaf et al., 2017). This result was in agreement with results of Meghana et al. (2019). The results also showed the positive effect of spraying AYE, where the BY increased with increasing the AYE concentration. The highest weight of BY being obtained (28.214 ton. ha ${ }^{-1}$ ) by using $\mathrm{Y}_{2}$ treatment with an increase by $11.1 \%$ compared to $\mathrm{Y}_{0}$ which gave the lowest BY (25.398 ton. $\mathrm{ha}^{-1}$ ). This is due to the role of AYE in an increasing some of biological processes which reflected in increasing vegetative growth, tillering, leaf area and grain yield leading to increased biological yield (Ismail \& Amin, 2014) This finding was in agreement with results of Sarhan et al. (2011). The interaction between the two factors had a significant effect in this characteristic. The combinations of $\mathrm{F}_{4} \mathrm{Y}_{2}$ and $\mathrm{F}_{2} \mathrm{Y}_{2}$ gave the highest $\mathrm{BY}$ reached to31.827 and 31.247 ton. ha $^{-1}$ respectively; while the lowest value obtained at the combination $\mathrm{F}_{0} \mathrm{Y}_{1}$ which reached to 20.427 ton. ha ${ }^{-1}$.

\section{Protein yield (kg. ha-1)}

The results of the statistical analysis and the data of fig. (2) showed that spraying of MN and AYE had a significant effect on the protein yield of wheat, while the interaction have no significant effect on this parameter. The highest protein yield was $1064.8 \mathrm{~kg}$. ha ${ }^{-1}$ obtained by using $F_{3}$ treatment, which did not differ significantly from $\mathrm{F}_{4}$ treatment, which gave a protein yield of $1053.2 \mathrm{~kg} \mathrm{ha}^{-1}$ with an increase of 35 and $34 \%$, respectively, compared to the control treatment $\left(\mathrm{F}_{0}\right)$. This may be due to the role of $\mathrm{MN}$, especially the role played by iron and molybdenum in an increasing the effectiveness of Nitrate $\left(\mathrm{No}_{3}\right)$ reductase enzyme

Table (7): Effect of micronutrients and spraying with AYE and their interaction

$$
\text { on biological yield (ton. ha- }{ }^{-1} \text { ) for wheat. }
$$

\begin{tabular}{|c|c|c|c|c|c|c|}
\hline \multirow{2}{*}{ Yeast levels } & \multicolumn{5}{|c|}{ Micronutrients levels } & \multirow{2}{*}{$\begin{array}{c}\text { Mean for } \\
\text { Yeast }\end{array}$} \\
\hline & $\mathrm{F}_{0}$ & $F_{1}$ & $\mathrm{~F}_{2}$ & $\mathrm{~F}_{3}$ & $\mathrm{~F}_{4}$ & \\
\hline $\mathrm{Y}_{0}$ & 22.367 & 23.177 & 23.931 & 28.189 & 29.359 & 25.405 \\
\hline $\mathrm{Y}_{1}$ & 20.427 & 25.034 & 26.143 & 27.883 & 30.823 & 26.062 \\
\hline $\mathrm{Y}_{2}$ & 25.339 & 26.199 & 31.247 & 27.598 & 31.827 & 28.442 \\
\hline $\begin{array}{c}\text { Mean for } \\
\text { Micronutrients }\end{array}$ & 22.711 & 24.803 & 27.107 & 27.890 & 30.670 & \\
\hline \multirow{2}{*}{ L.S.D. $(\mathrm{P}<0.05)$} & \multicolumn{2}{|c|}{ Micronutrients } & \multicolumn{2}{|c|}{ Yeast } & \multicolumn{2}{|c|}{ Interaction } \\
\hline & \multicolumn{2}{|c|}{2.971} & \multicolumn{2}{|c|}{1.182} & \multicolumn{2}{|c|}{2.644} \\
\hline
\end{tabular}




\section{Al-Shamary \& Huthily. / Basrah J. Agric. Sci., 32(2):105-115, 2019}

and consequently increase the nitrogen content in the seeds and then increase the protein yield (Al-Jubouri, 2015). Such increase of protein yield is due to the increase in grain yield and nitrogen concentration at this level. The protein yield exhibits behavior as that of the seed (Meghana et al., 2019).

The results of fig. (2) also indicate the significant effect of spraying with AYE.Y 2 treatment gave the highest protein yield of
$1017.3 \mathrm{~kg}$. ha ${ }^{-1}$ compared to the no-spray treatment $\left(\mathrm{Y}_{0}\right)$ which gave the lowest protein yield of $917.1 \mathrm{~kg}$. ha ${ }^{-1}$, with an increase by $10.9 \%$ as compared to the control treatment. This may be due to the different contents of yeast like: acids, vitamins, growth regulators and nutrients that have an active role in anincreasing the protein yield. This is consistent with what Al-Shammary \& Salman (2011) found.

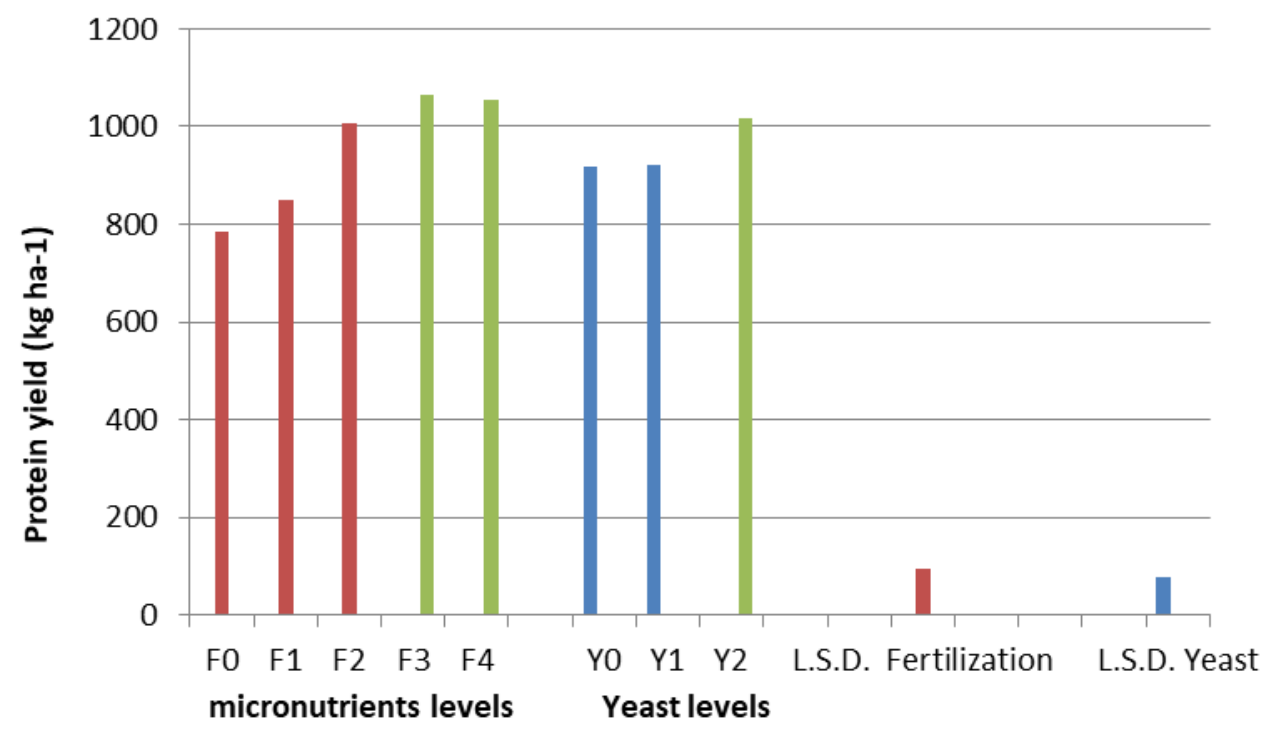

Fig. (2): Effect of micronutrients and spraying with AYE on protein yield ( $\left.\mathrm{kg} \mathrm{ha}^{-1}\right)$ for wheat. 


\section{Al-Shamary \& Huthily. / Basrah J. Agric. Sci., 32(2):105-115, 2019}

\section{Conclusions}

It can concluding that spraying of micronutrients in concentration of $1000 \mathrm{ppm}$ and using 6 gm yeast. $1^{-1}$ affected significantly and gave the highest grain, biological and protein yield. The interaction between the two factors $\left(\mathrm{F}_{4} \mathrm{Y}_{2}\right)$ recorded the highest grain yield reached to 8.891 ton ha $^{-1}$ with an increasing percent by $33.4 \%$ compared to control $\left(\mathrm{F}_{0} \mathrm{Y}_{0}\right)$.

\section{Acknowledgments:}

My thanks and appreciation to the Chairman $\&$ members of the Department of Field Crops, for their cooperation with me to complete my master's thesis.

Conflict of interest: The authors declare that they have no conflict of interest.

\section{References}

Abu-Dahi, Y. M. (1995). The Effect of leaf feeding with green Zit-3 on growth, harvesting and quality of wheat grain Triticum aestivum L. for Abu Ghraib cultivar 3. The Iraqi J. Agric. Sci., 26: 3036. (In Arabic).

Abu-Dahi, Y.M. \& Shati, R.K. (2009). Effect of foliar feeding of iron, zinc and potassium on growth and yield of wheat. Iraqi J. Agric. Sci., 40(1): 69-81. (In Arabic).

Al-Alusi, Y.A.M. (2002). Effect of spraying with iron and manganese in potassiummixed soils on wheat growth and yield. $\mathrm{Ph}$. D. Thesis. Coll. Agric. Univ. Baghdad. 78pp. (In Arabic).

Al-Ani, M. H.I. \& Al-Obeidi, N. D.A. (2017). Response of varieties of maiza to bio-fertilization of bread yeast Saccharomyces cerevisiae L. Al-Anbar J. Agric. Sci., 15(2): 471-383. (In Arabic).
Al-Hamdani, G.A.; Taha, B.N. \& Al-Jubouri. E.S. (2014). The effect of bio-enriched EMI and yeast suspension on the quantitative traits of the quaternary wheat (Triticum durum Desf.) M. Sc. Thesis, Coll. Sci. Univ. Mosul: 131pp. (In Arabic).

Al-Hassan, R.S.H. (2017). Response of three varieties of wheat Triticum aestivum $\mathrm{L}$. to the bacterial vaccine Azotobacter chroococcum and boron spraying. M. Sc. Thesis. Coll. Agric. Univ. Basrah: 94pp. (In Arabic).

Al-Jubouri, F.D.F. (2015). Effect of molybdenum and spraying with boron on growth and yield of broad bean (Vicia faba L.). M. Sc. Thesis. Coll. Agric. Univ. Basrah: 90pp. (In Arabic).

Al-Jumailly, I.A.S. (2011). Effect of foliar application of micronutrient spraying on growth and yield of three wheat varieties. Anbar J. Agric. Sci., 9(2): 80-90. (In Arabic).

Al-Maeini, W.K.A. \& Al-Isawi, Y.J.A. (2017). Effect of foliar application of yeast extract on seed yield components of five sorghum cultivars. Anbar J. Agric. Sci., 15(1): 152-161. (In Arabic).

Al- Shammary, A.S.H. \& Salman, N.D. (2011). Effect of bio-organic and mineral fertilization on the growth and yield of wheat. M. Sc. Thesis. Coll. Agric. Univ. Baghdad: 117pp. (In Arabic).

Al-Tameme, M.S. (2013). Response of two varieties of wheat to spray iron and zinc. Euphrates J. Agric. Sci., 5(3): 122-130. (In Arabic).

Al-Zergawy, M.A.A. (2016). Effect of foliar an-Nebras colloidal fertilizer at different growth stages on growth, yield and yield components of Barley (Hordeum vulgar 


\section{Al-Shamary \& Huthily. / Basrah J. Agric. Sci., 32(2):105-115, 2019}

L.). Basrah J. Agric. Sci., 29(2): 502--513. (In Arabic).

De Wedar, G.A. \& Ibrahim, E.A.M. (2016). Effect of foliar application of yeast on yield and seed quality of some rice cultivars. Plant Prod. Univ., 7(6): 593-601.

El-Desouky, S.A., Wanas, A.L.; Khedr, Z.M V.A. \& Kandiann, K. (2007). Utilization of parthasara the horticulthre. vegetable some natural plant extracts (of garlic and yeast) as seed soaked materials to squash (Cucurbatia pepo L.) 1. Effect on growth, sex expression and fruit yield \& quality. J. Agri. Sci. Moshtohor Zagazig Univ., 35(2): $839-854$.

Ezz El-Din, A.A. \&. Hendawy, S.F. (2010). Effect of dry yeast and compost tea on growth and oil content of Borago officinalis. Res. J. Agri. Biol. Sci., 6(4): 424-430.

Hussein, W.A.H. \& Khalaf, L.Q. (2008). Some growth and productivity standards for potato yield after spraying with Different Concentrations of yeast solution J. Nahrain Univ., 11(1): 33-37. (In Arabic).

Ismail, M.A. \& Amin, M.A. (2014). Response of wheat (Triticum aestivum L.) plants to foliar spraying of some bio-stimulants (yeast extract, arginine, $\mathrm{B}_{12}$ and their interactions. Al Azhar Bull. Sci., 25(2): 110. (In Arabic).

Khalaf, T.I.; Bassima A.A \& Araak, R.R. (2017). Effect of soil and foliar fertilization using Humzinc compound on some growth and yield characters of wheat (Triticum aestivum L.). Karbala J. Agric. Sci., 4(1): 62-73. (In Arabic).
Meghana S.; Kadalli G.G; Prakash S.S. \& Fathima P.S. (2019). Effect of micronutrients mixture on growth and yield of aerobic rice. Int. J. Chem. Stud., 7(2): 1733-1735.

Mohamed, M.F.; Thaloth, A.T.; Essa, R.E.Y. \& Mirvat, E. (2018). The stimulatory effects of Tryptophan and yeast on yield and nutrient status of wheat (Triticum aestivum ) grown in newly reclaimed soil. Middle East J. of Agric. Res., 7(1): 27-33.

Neama, N.M.; Shafeek, M.R.; Helmy, Y.I.; Ahmed, A.A. \& Magda, A.F.S. (2014). Effect of vitamin $\mathrm{E}$ and yeast extract foliar application on growth, pod yield and both green pod and seed yield of broad bean (Vicia faba L.). Middle East J. Sci., 4(1): 61-67.

Rawashdeh, M.H. \& Sala, F. (2014). Foliar application of boron on some yield components and grain yield of wheat. Acad. Res. J. Agri. Sci. Res., 2(7): 97-101.

Salim, S.C. \& Ali, N.S. (2017). Directory of chemical analyzes of soil, water, plants and fertilizers. Min. Hig. Educ. Sci. Res. Univ. Baghdad. Coll. Agric.: 307pp. (In Arabic).

Salman, F.A. \& Aliwi, Z.H. (2017). Effect of spraying yeast and urea fertilizer on some indicators of vegetative growth and productivity of pumpkin (Cucurbitia pepo L.) J. Babylon Univ. Pure Appl. Sci., 25(4): 1452-1457. (In Arabic).

Sarhan, T.Z.; Ali, S.T.S. \& Rasheed, M.S. (2011). Effect of bread yeast application and seaweed extract on cucumber (Cucumis sativus L.) plant growth, yield and fruit quality. Mesopotamia J. Agric., 39(2): 26-34. 